\title{
Virtual Technologies possibilities for improving background knowledge of Civil Engineering Education
}

\section{Olga Ovtšarenko ${ }^{1}$, Daiva Makuteniene ${ }^{2}$, Edgaras Timinskas ${ }^{2}$}

${ }^{1}$ Centre for Sciences, TTK University of Applied Sciences, Estonia, ${ }^{2}$ Department of Engineering graphics Faculty of Fundamental Sciences, Vilnius Gediminas Technical University, Lithuania.

\begin{abstract}
A new era with rapid technological changes, digitization, new forms of labour organization requires innovative ideas for modern education using a virtual learning environment and available technical means. This article discusses the prerequisites for creating a concept of a universal curriculum for first-year students in construction specialities for teaching the fundamentals of technical disciplines - that means basic engineering education, with integrating the Building Information Modeling (BIM).

The Building Information Modeling (BIM) methodology includes the concept of combined information about all the parameters of a three-dimensional object. This is universally supported by modern technology and can be used to develop innovating teaching methods.

To identify the prerequisites for the concept of a universal electronic course, an analysis of the IMD statistics was carried out and a generalized overview of the content of educational programs in the main technical disciplines of higher educational institutions of the countries of one graphic region was conducted.
\end{abstract}

Keywords: BIM; Virtual Technology; First-Year Student; Civil Engineering Education. 


\section{Introduction}

The main task of modern higher technical education is to provide the labour market with specialist engineers with the necessary knowledge and skills to perform work tasks of various levels of complexity (Tabas at. all, 2018).

The need to review and analyze the curricula of several higher educational institutions of the countries of one graphic region to study the main technical disciplines is probably due to the difference in the teaching of higher technical education in neighbouring countries, which affects the statistical indicators of the countries competitiveness as a whole and the success of specialists' work.

Comparison, analysis and generalisation of learning outcomes of first-year basic technical subjects will help assess the possibility to use an integration of BIM - Building Information Modelling (Hjelseth, 2018).

The three-dimensional modelling program Revit allows us to create different threedimensional objects for visualizing and a better understanding of educational topics since it is Revit objects that contain complete parametric information about the object and its parts, as well as use information parameters a particular object throughout its entire life cycle.

\section{Research methodology}

\subsection{Analysis of statistical information}

Analysis of the statistics of the world ranking of countries' success is necessary to determine and select universities with similar ratings and geographic positions, whose curricula are supposed to be analyzed.

For the study, it is necessary to analyse statistical information of the world and regional ratings taking into account the regional grouping of countries (Table 1). 
Table 1. Composition of sub-regions and regions of Europe.

\begin{tabular}{lllll}
\hline Western & Austria & Netherlands & France & Switzerland \\
Europe & Italy & Denmark & Spain & Iceland \\
& Belgium & Norway & Germany & United Kingdom \\
& Luxembourg & Finland & Sweden & Ireland \\
& Cyprus & Portugal & Greece & \\
\hline Eastern & & Bulgaria & Estonia & Hungary \\
Europe & & Latvia & Romania & Slovak Republic \\
& & Czech Republic & Croatia & Lithuania \\
& & Poland & Slovenia & Ukraine
\end{tabular}

Source: IMD WORLD TALENT RANKING 2019 (November 2019)

Then, according to the analysis of the Global Talent Rating, it is necessary to find out in which countries of the same region IMD indicators are approximately at the same level.

IMD evaluates three factors: the Investment and Development, the Appeal, and the Readiness factor (Table 2) .

Table 2. The IMD World Talent Ranking 2019.

\begin{tabular}{clccccc}
\hline $\begin{array}{c}\text { Overall } \\
\text { Rank 2019 }\end{array}$ & Country & $\begin{array}{c}\text { One Year } \\
\text { Change }\end{array}$ & $\begin{array}{c}\text { Overall } \\
\text { Score 2019 }\end{array}$ & $\begin{array}{c}\text { Investment \& } \\
\text { Development }\end{array}$ & Appeal & Readiness \\
\hline 1 & Switzerland & - & 100.00 & 2 & 1 & 2 \\
6 & Norway & -3 & 85.95 & 3 & 10 & 21 \\
8 & Finland & -1 & 83.14 & 10 & 16 & 3 \\
11 & Germany & -1 & 80.78 & 11 & 9 & 14 \\
27 & Estonia & +1 & 66.88 & 21 & 23 & 35 \\
28 & Lithuania & +8 & 66.51 & 14 & 35 & 33 \\
31 & Slovenia & -1 & 64.16 & 22 & 42 & 30 \\
34 & Latvia & +1 & 62.08 & 12 & 48 & 40 \\
\hline
\end{tabular}


One of the key characteristics of leading economies is that they strive to achieve alignment between talent the demand they face and the internal supply of talent they are able to offer.

In the Table 3, there is showed the ranking of the three leading economies in the region with indicators for three factors. It can be seen that regions have different strengths in relation to the factors studied.

Table 3. Ranking of Eastern Europe countries.

\begin{tabular}{ccccc}
\hline Ranking & Country & $\begin{array}{c}\text { Investment } \\
\text { \& Development }\end{array}$ & Appeal & Readiness \\
\hline $\mathbf{2 7}$ & Estonia & 21 & 23 & 35 \\
$\mathbf{2 8}$ & Lithuania & 14 & 35 & 33 \\
$\mathbf{3 4}$ & Latvia & 12 & 48 & 40 \\
\hline
\end{tabular}

Source: IMD WORLD TALENT RANKING 2019 (November 2019).

This sub-region is led by Estonia, Lithuania follows, and Latvia closes the sub-regional top (IMD, 2019). The ranking shows the proximity of positions in the economic achievements of countries, which is the rationale for the choice of educational programs of universities for further study.

\subsection{Learning outcomes of higher technical educational institutions}

According to the above world ranking data, universities from the countries of one subregion - Eastern Europe - Estonia, Lithuania, Slovakia, as well as countries with a high rating of Western Europe - Norway, Finland and Germany - were selected for comparative analysis of programs of basic technical subjects of the first year of study and summarizing the results of the analysis. The results of training in the specialities of construction (Tabas, B., Beagon, U., \& Kövesi, K. (2018) were summarized by teachers of the TTK UAS Estonia, Relevance of competence according to Graduate Attributes and Professional Competencies (2014), and are shown in Table 4. 
Table 4. Construction specialty programs' learning outcomes.

\section{Learning outcomes}

\section{Relevants of competence}

1. the need to study and understand the design and construction processes, interaction and coordination of work processes between partners of the construction process both locally and internationally.

2. acquisition of the fundamental knowledge on building technologies, on managing execution of smaller structures, on production of building materials for designing of simple constructions, presenting own solutions of technical and economical issues within construction of various types of constructions.

The educational outputs of all programs correspond to the tasks of training competitive specialists - civil engineers design and calculate, build, plan and manage the work of the industry. Requirements of qualified preparation for solving today's construction problems, such as changes in the environment and climate, due to industry expectations regarding innovation and production, since Civil Engineering goals are the development of the main infrastructure needed for society: the assessment, planning, design, construction, operation and maintenance of infrastructural works (Hjelseth, 2015).

\section{Background for the development of a modern universal curriculum design}

\subsection{The meaning of engineering thinking}

Engineering thinking should ensure the use of acquired knowledge to solve practical problems that were or were not taken into account during his training. In other words, the engineer must be able to apply all the knowledge gained and find the optimal solution for a standard or non-standard task, which means processing the initial data about the object, creating and regulating the relationships between the parameters of the object or between objects, or between the object and the environment. 
Therefore, the task of higher technical education is to choose such subjects that provide the necessary set of knowledge to ensure engineering thinking, and it is very important to start with basic technical subjects of the first year of study. The first year of study is difficult for students - entering a new learning environment with new information, requirements, terminology, the need to independently plan and carry out academic work. Therefore, the content and form of basic technical subjects should be intuitive, interactive, with mandatory feedback so that the student can work independently to achieve the desired level of knowledge.

The problem of using innovative teaching materials after changing them is to update the content, develop new exercises for students' practical and independent work, require their implementation and adaptation, and then track the success of their use. This process takes some time, and by the time it is accepted and approved for use in training, often innovative teaching materials are outdated and lose their innovative value.

The use of BIM in education is possible for the creation of small courses or modules of large course-integrated interdisciplinary projects and distance cooperation between higher education partners.

The task of integrating and adopting BIM into existing courses and curricula is more important because it is primarily a convenient visualization tool.

\subsection{Mobile learning}

Accessible basic education should include various teaching methods. New technologies have greatly expanded learning opportunities with mobile devices. Now users can access a huge amount of the data they need without restrictions at a convenient time for them.

The younger generation is very interested in learning through interactive mobile applications - whether it be videos, presentations, virtual reality VR, augmented reality AR or gaming learning applications. This democratization of VR/AR will increase accessibility and affordability of VR/AR, and these technologies will be something as usual as mobile technologies within next few years, making it easier to integrate VR/AR (Martin-Gutiérrez, 2017).

Online training courses consisting of short videos and game exercises, simulators, tests are very effective due to their simplicity, cost-effectiveness and form of the game (Ovtšarenko at. al, 2019).

Group training is also very effective using mobile devices - between groups of people in discussion forums, blogs, social networks there is an exchange of ideas and information.

E-books also provide an excellent opportunity for mobile learning. 
Mobile learning expands the scope of training by providing access to quality content not only from the classroom.

Investment in this field of mobile learning using technologies such as AR/ VR, Artificial Intelligence AI, robotics, and blockchain in education is rapidly growing and in 2025 it will be $\$ 22$ billion compared to 2018 \$4 billion (Thomas A Singlehurst et. al, 2019).

\subsection{Learning modules}

The concept of creating small training modules for one course has many advantages, including the sequence and coordination of training topics with each other, the repetition and consolidation of basic knowledge on various topics with the creation of logical chains of connections, additions to the knowledge gained. There is possible to use small training modules to create intersubject communications, which is an indisputable advantage. Elearning can also be used as timely support for a core e-learning course, helping users quickly view past exercises and tests, using personalized access to digital content and speeding up the learning process.

\subsection{Integration BIM into existing courses}

The problem of using innovative teaching materials after their development and change is to update the content, develop new exercises for students' practical and self-work, perform and adapt them, and then track the success of their use. This process requires considerable time and often innovative teaching materials - by the time it is accepted and approved for use in training, it is outdated and loses its innovative value. The integration of BIM into existing academic subjects will help, first of all, to visualize any topic of a technical subject, which will significantly reduce the time for understanding and mastering knowledge on this topic. In addition, to ensure intersubject communications of basic subjects - graphics, physics and mathematics - with use of the same spatial objects will significantly enrich and complement the content of these educational subjects, the teaching process will be very effective, with the introduction of parametric modelling. As the most advanced technological solution, engineers need BIM knowledge and technology. To reduce the loss of time spent learning BIM, the best solution is to integrate and adapt BIM into existing courses and training programs, rather than organizing individual BIM courses (Hjelseth, 2018).

\section{Conclusion and recommendations}

BIM, included in other subjects, is important as a means of improving learning, for student work and collaboration (Sampaio, 2018).

The expected impact - the inclusion of BIM in existing academic subjects can help increase the competencies of future specialists and their competitiveness. 
Significant changes in the content of traditional subjects using visualization and parametric information of educational objects, the use of mobile devices will increase not only the interest of students but also increase the effectiveness of the educational process (Lassen at. all, 2018). And the use of BIM at an early stage in the training of specialists can be achieved without major formal changes in the curriculum.

Connection with modern technologies used - students' participation in ongoing work projects using BIM provides an opportunity for more in-depth training, cooperation.

Three-dimensional modelling programs allow us to create various three-dimensional objects for visualization and a better understanding of educational topics since objects contain parametric information about the object and its parts, which allows you to create intersubject communications and use them effectively for better assimilation of logically related educational material.

\section{References}

Graduate Attributes and Professional Competencies. IEA, Version 3: 21, June 2013. Retrieved from: http://www.ieagreements.org/assets/Uploads/Documents/Policy/Graduate-Attributesand Professional-Competencies.pdf

Hjelseth, E. (2018). Experience from Norway on implementing BIM in existing bachelor engineering curriculum. In J. Karlshoj, \& R. Scherer (Eds.), eWork and eBusiness in Architecture, Engineering and Construction: Proceedings of the 12th European Conference on Product and Process Modelling (ECPPM 2018), September 12-14, 2018, Copenhagen, Denmark

Hjelseth, E. (2015). Use of BIM for learning engineering - Change of paradigm. Proc. of the 32nd CIB W78 Conference 2015, October 27th-29th 2015, Eindhoven, The Netherlands, 275-284. https://pdfs.semanticscholar.org/b4fb/7995136924bad719d1693dc436c915025ba5.pdf

IMD WORLD TALENT RANKING 2019 (November 2019). IMD: Institute for Management Development. Retrieved from: https://www.imd.org/wcc/worldcompetitiveness-center-rankings/world-talent-ranking-2019/

Lassen, A. K., Hjelseth, E., \& Tollnes, T. (2018). Enhancing learning outcomes by introducing BIM in civil engineering studies -experiences from a university college in Norway. International Journal of Sustainable Development and Planning. vol. 13 (1), 62 - 72. Retrieved from: https://www.witpress.com/elibrary/sdp-volumes/13/1/1791

Martín-Gutiérrez, J., Mora, C. E., Añorbe-Díaz, B., \& González-Marrero, A. (2017). Virtual technologies trends in education. EURASIA Journal of Mathematics Science and Technology Education, 13(2), 469-486. DOI:https://doi.org/10.12973/eurasia.2017.00626a. Retrieved from: https://www.researchgate.net/publication/311373822_Virtual_Technologies_Trends_in _Education 
Ovtšarenko, O., Safiulina, E., Makuteniene, D., \& Timinskas, E. (2019). Use of Digital Objects for Improving the Learning Process. In F. Soares, A. P. Lopes, K. Brown, \& A. Uukkivi (Eds.), Developing Technology Mediation in Learning Environments (Chapter 16). IGI Global. DOI: 10.4018/978-1-7998-1591-4

Sampaio, A. Z. (2018). Introduction of BIM methodology in education: Concept and Application. 4th International Conference on Higher Education Advances (HEAd'18), 19-27. doi: 10.4995/HEAd18.2018.8228.

Singlehurst, T., Pejaver, N., Li, M., Gong, B., \& Channell, J., (2019). Education: Power to the people. Exploring Opportunities for Private Capital in Education. Citi GPS: Global Perspectives \& Solutions, November 2019. Retrieved from https://ir.citi.com/zwaEqN9YmEuQZ3IxTxz0CB9Cjw5ZT9XEvE6D\%2BOgHqO70Wr gFdMJNjtS8k0HbjQHOM69MRBTlcJQ\%3D

Tabas, B., Beagon, U., \& Kövesi, K. (2018). Report on the future role of engineers in society andthe skills and competences engineering will require

Retrieved from: https://www.astep2030.eu/sites/sub_site_astep2030/files/201905/report_1_literature_review_a-step_2030_a1_t1_.pdf 